\title{
Ecophysiological aspects of sun and shade leaves of Ponkan tangerine (Citrus reticulata Blanco)
}

\author{
Aspectos ecofisiológicos de hojas de sol y sombra de Ponkan mandarina \\ (Citrus reticulata Blanco) \\ Eduardo Domingos Grecco ${ }^{1 *}$, Luiz Flávio Vianna Silveira ${ }^{1}$, Victor Luiz de Souza Lima ${ }^{1}$, \\ José Eduardo Macedo Pezzopane 1
}

\begin{abstract}
The Ponkan tangerine (Citrus reticulata) has wide acceptance by consumers due to several properties; it is a colorful, sweet, and easy to peel fruit. The purpose of this study was to evaluate ecophysiological aspects of the response of plants of Ponkan tangerine to shading, according to relative intensity of light, in order to assess the adaptability of this species to shade. Leaves were collected from the upper canopy (sun) and lower canopy (shade) to determine the ecophysiological aspects. Cuts were by hand made to assess the thickness of palisade parenchyma, number of stomata $\left(\mathrm{mm}^{2}\right)$ and total thickness of the leaf. Cross-sections of the middle part of leaves were obtained to assess the parenchyma, using a body-of-evidence, and for the stomata cuts were made on the abaxial surfaces. Chlorophyll was extracted from the leaves of Ponkan Tangerine and subsequently measured in a spectrophotometer at wave lengths $645_{\mathrm{nm}}$ and $663_{\mathrm{nm}}$. The ratio between chlorophyll a and b tended to increase with increased intensity of light. Shading did not affect the anatomical characteristics of Ponkan tangerine plants. However, chlorophyll levels were different in sun and shade leaves.
\end{abstract}

Key words: Ponkan Tangerine, anatomical characteristics, chlorophyll, shading.

\section{RESUMEN}

Ponkan mandarina (Citrus reticulata) tiene una amplia aceptación por los consumidores debido a varios aspectos: es una fruta colorida, cáscara dulce y fácil de pelar. El propósito de este estudio fue evaluar la respuesta a la sombra de las plantas de Ponkan mandarina (Citrus reticulata) respecto de sus aspectos ecofisiológicos, de acuerdo con la intensidad relativa de la luz, a fin de evaluar la capacidad de adaptación de esta especie para dar sombra. Las hojas se obtienen de la cubierta superior (sol) y la cubierta inferior (sombra) para la determinación de los aspectos ecofisiológicos. Cortes en las manos se hicieron para la evaluación del espesor de parénquima de empalizada, número de estomas $\left(\mathrm{mm}^{2}\right)$ y el espesor total de la hoja. Las secciones transversales de la parte media de la licencia se obtuvieron, para la evaluación de la parénquima, utilizando un cuerpo de evidencia, y para el estomática se hicieron cortes en la superficie abaxial. La clorofila se extrajo de las hojas de mandarina Ponkan y posteriormente se mide en espectrofotometría a longitudes de onda de $645_{\mathrm{nm}}$ y $663_{\mathrm{nm}}$. La relación entre la clorofila a y b tendía a aumentar con una mayor intensidad de luz. El sombreado no afectó a las características anatómicas de las plantas de mandarina Ponkan. Sin embargo, los niveles de clorofila fueron diferentes en "sol" y se va "sombra".

Palabras clave: Ponkan mandarina, características anatómicas, clorofila, sombreado.

Citrus crops have a prominent position in Brazil, both in production volume and growing area (Figueiredo, 1999). The Ponkan mandarin (Citrus reticulata) is widely accepted by consumers because it is a colorful, sweet, easy-to-peel and large fruit compared to other citrus crops on the market (Figueiredo, 1991).
Not only the concentration of chlorophyll, but also the ratio between the different kinds of chlorophyll change depending on light intensity. It has been demonstrated that the ratio between chlorophyll a and b usually tends to decrease with the decreasing intensity of light (Whatley \& Watley, 1982). A higher relative ratio of chlorophyll $b$ in

\footnotetext{
1 Centro de Ciências Agrárias da Universidade Federal do Espírito Santo, Alto Universitário, CP-16, CEP: 29.500-000, Alegre, Espírito Santo, Brasil.

* Corresponding author: jemp@cca.ufes.br.
}

Fecha de Recepción: 5 Marzo, 2013.

Fecha de Aceptación: 10 Septiembre, 2014. 
shaded plants is an important characteristic, because it enables the absorption of radiant energy of other wavelengths and its transfer to a specific molecule of chlorophyll a that effectively participates in the photochemical reactions of photosynthesis (Whatley $\&$ Whatley, 1982). This relative increase may be linked to an increased rate of chlorophyll $\mathrm{a} / \mathrm{b}$ binding in the protein collection complex, associated with photosystem I in the "grana", in relation to the $\mathrm{P}$ 700 complex (which contains only chlorophyll a protein) from photosystem II in the thylakoids that is easily photo-oxidized (Thornber, 1975). Another factor may be the higher ratio of "grana" in chloroplasts of shaded leaves (Mitchell, 1979).

Among the various environmental components, light is essential for plant growth not only because it provides energy for photosynthesis, but also for providing signals that regulate their development through light receptors sensitive to different intensity, spectral quality and state of polarization. Therefore, changes in the light levels to which a species is adapted may lead to different physiological responses in its biochemical, anatomical and growth characteristics (Atroch et al., 2001). The anatomy of the leaf is highly specialized for light absorption, and the properties of the mesophyll, especially those of the palisade parenchyma, ensure uniform light absorption throughout the leaf.

The decrease in $\mathrm{CO}_{2}$, assimilation caused by water deficit may be due to stomatal closure, restricting the inflow of $\mathrm{CO}_{2}$ in the mesophyll cells, and/or to effects of stress directly on photosynthetic mechanisms (Kaiser, 1987; Chaves, 1991). The stomata can respond quickly to changes in air and/ or soil humidity and to interaction between these two factors (Syvertsen \& Lloyd, 1994; Brakke \& Allen Jr., 1995).

Under natural conditions, in citrus crops the reduced photosynthesis during water deficit in the soil is more pronounced in the warmest times of the day when vapor pressure deficit is higher (Syvertsen \& Lloyd, 1994; Brakke \& Allen Jr., 1995; Medina et al., 1999).

This study aimed to investigate ecophysiological aspects of the response to shading of the Ponkan tangerine (Citrus reticulata) according to the relative intensity of light, in order to assess the adaptability of this species to shade, testing the hypothesis that this more shade-tolerant species would be better able to change the levels of chlorophyll in the leaf. In this study leaves of Ponkan tangerine were used, which were removed from orchards of Alegre, Brazil in two treatments: leaves collected from the upper canopy ('sun') and from the lower canopy ('shade') for the determination of ecophysiological aspects. The experimental design was completely randomized with five replicates for assessment of anatomical aspects and chlorophyll. The experiments were conducted at the Center for Research and Technology Dissemination in Forests, Water and Sustainable Agriculture (NEDTEC) of the Center for Agricultural Sciences, Federal University of Espirito Santo (CCA-UFES), in the city of Jerônimo Monteiro, Brazil.

The leaves of Ponkan tangerines were cut by hand to assess the thickness of palisade parenchyma, number of stomata $\left(\mathrm{mm}^{2}\right)$ and total thickness of the leaf. Cross-sections of the middle part of leaves were obtained to assess the parenchyma, using a body-of-evidence, and cuts were made on the abaxial surfaces for the stomata. The sections were mounted onto slides, and the images were capured by a digital camera mounted on an optical microscope. The measurements of the thickness of the leaves and counts of the number of stomata per area were performed using the software Image Pro-Plus for Windows (IPWIN) version 1.1.

For the extraction of chlorophyll, $10 \mathrm{~g}$ of Ponkan tangerine leaves were weighed for the five replicates, macerated in a crucible with calcium carbonate $\left(\mathrm{CaCO}_{3}\right)$ and washed sand, then filtered with filter paper. Acetone $(80 \%)$ was added as the volume decreased in the filter until the Erlenmeyer flask was filled to the $50 \mathrm{~mL}$ mark. The spectrophotometric measurements were made according to the absorbance reading using quartz cuvettes in an S-600 spectrophotometer at wavelengths $645_{\mathrm{nm}} 647_{\mathrm{nm}}$ and $663_{\mathrm{nm}}$. For calculations of the chlorophyll content only wavelengths $645_{\mathrm{nm}}$ and $663_{\mathrm{nm}}$ were used.

The calculations of $\mathrm{mg}$ of chlorophyll per gram of fresh weight of leaf tissue were based on the following equations (1), (2), and (3) (Arnon, 1949):

(1) Chlorophyll $\mathrm{a}=[(12.7 \times \mathrm{A} 663)-(2.64 \mathrm{x}$ A645)] (mg/g)

(2) Chlorophyll $\mathrm{b}=[(22.9 \times \mathrm{A} 645)-(4.68 \mathrm{x}$ A663)] (mg/g)

(3) Total Chlorophyll = Chlorophyll a + Chlorophyll $\mathrm{b}(\mathrm{mg} / \mathrm{g})$ 
Where:

A645 - Reading of the device at $\lambda(645 \mathrm{~nm})$. A663 - Reading of the device at $\lambda(663 \mathrm{~nm})$.

The significance of differences between the quantitative anatomical parameter measures was determined by Student's t-test at 5\%.

The results presented in Table 1 show significant differences between the anatomical characteristics studied: EFT $=$ total thickness of the leaf $(\mu \mathrm{m})$; $\mathrm{PP}=$ thickness of palisade parenchyma, $(\mu \mathrm{m})$; $\mathrm{DE}=$ stomatal density (stomatal. $\mathrm{mm}^{2}$ ). The characteristics of chlorophyll a, b, total, and chlorophyll $\mathrm{a} / \mathrm{b}$ ratio $(\mathrm{mg} / \mathrm{g})$ were also found to be significant.

These anatomical differences, combined with morphological changes in leaf epidermis, demonstrate that leaves are susceptible to changes in light intensity. This factor can promote changes in leaf thickness and area in the intercellular spaces, in the number of layers of the mesophyll and in photoassimilate distribution (Lawlor, 1987). The physiological differences between "sun" and "shade" leaves were also partially attributed to differences in leaf structure (Gratani et al. 2006). Under shade conditions the leaves are usually less thick than normal as a consequence of underdevelopment of mesophyll tissues. This feature is interpreted as an adaptation that reduces the costs involved in maintaining cells capable of $\mathrm{CO}_{2}$ fixation, reduced because of the decrease in availability of sunlight.

According to Taiz \& Zeiger (2004), greater thickness of the palisade parenchyma can avoid photoinhibition in leaves exposed to high light intensity. Studies with woody species have shown thicker mesophyll tissues and reduction of intercellular spaces in plants grown in bright sunlight compared to plants grown with higher levels of shade (Nakazono et al., 2001; Piel et al., 2002).

The levels of chlorophyll content were higher in sun than in shade leaves (Table 2), showing greater efficiency in the absorption of photons ( $\lambda \max$ ) in the 428 and $660 \mathrm{~nm}$ regions. This interval is shorter than the absorption of solar radiation by chlorophyll a. A higher relative ratio of chlorophyll $b$ in shaded plants is an important characteristic because it enables the absorption of radiant energy of other wavelengths and its transfer to a specific molecule of chlorophyll a that effectively participates in the photochemical reactions of photosynthesis (Whatley \& Whatley, 1982).

The total chlorophyll content of the sun leaves was lower than that of the shade leaves (Table 2). According to Kramer \& Kozlowski (1979) chlorophyll is constantly synthesized and destroyed (photo-oxidation) in the presence of light, but under very high light intensities the rate of decomposition

Table 1. Anatomical characteristics observed in sun and shade leaves of Ponkan tangerine (Citrus reticulata) where, $\mathrm{EFT}=$ total thickness of leaf $(\mu \mathrm{m}) ; \mathrm{EPP}=$ thickness of palisade parenchyma $(\mu \mathrm{m})$;

$\mathrm{DE}=$ stomatal density $\left(\right.$ stomatal. $\left.\mathrm{mm}^{2}\right),( \pm \mathrm{EP})$.

\begin{tabular}{lccc}
\hline & EFT & EPP & DE \\
\hline 'Shade' leaves & $183.52 \pm 3.83^{\mathrm{b}}$ & $53.10 \pm 7.75^{\mathrm{a}}$ & $7.95 \pm 0.64^{\mathrm{b}}$ \\
'Sun' leaves & $201.20 \pm 5.50^{\mathrm{a}}$ & $2.87 \pm 3.25^{\mathrm{b}}$ & $12.45 \pm 0.85^{\mathrm{a}}$ \\
\hline
\end{tabular}

Means in the same column with different letters differ by $\mathrm{t}$ test $(\mathrm{P}<0.005)$.

Table 2. Levels of chlorophyll a (Cla), chlorophyll b ( $\mathrm{Clb})$ and total chlorophyll (Clt) and chlorophyll a/ $\mathrm{b}$ ratio $(\mathrm{Cla} / \mathrm{Clb})(\mathrm{mg} / \mathrm{g})$ in plants of Ponkan tangerine (Citrus reticulata), $( \pm \mathrm{EP})$.

\begin{tabular}{lcccc}
\hline & $\mathrm{Cla}$ & $\mathrm{Clb}$ & $\mathrm{Clt}$ & $\mathrm{Cla} / \mathrm{Clb}$ \\
\hline 'Shade' leaves & $0.59 \pm 0.013^{\mathrm{b}}$ & $0.65 \pm 0,012^{\mathrm{a}}$ & $1.24 \pm 0.024^{\mathrm{a}}$ & $0.91 \pm 0.001^{\mathrm{a}}$ \\
'Sun' leaves' & $0.77 \pm 0.027^{\mathrm{a}}$ & $0.39 \pm 0.043^{\mathrm{b}}$ & $1.14 \pm 0.067^{\mathrm{b}}$ & $1.91 \pm 0.002^{\mathrm{b}}$ \\
\hline
\end{tabular}

Means in the same column with different letters differ by t test $(\mathrm{P}<0.005)$. 

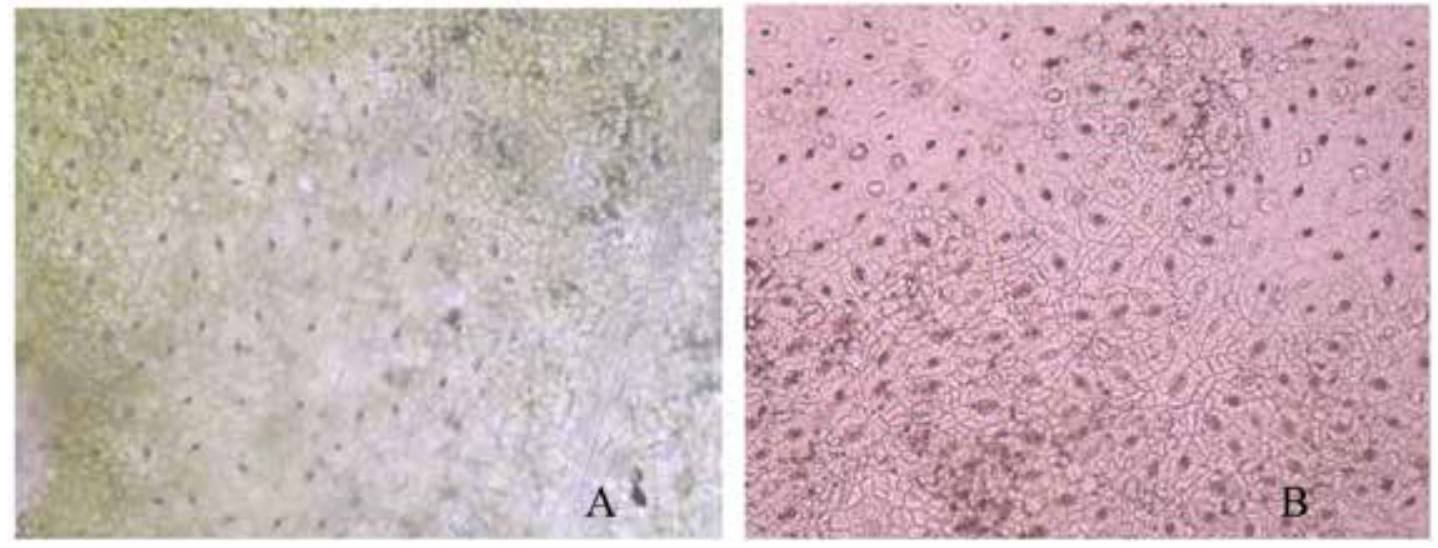

Figure 1. Difference in the number of stomata per $\mathrm{mm}^{2}$ of leaf of Ponkan tangerine (Citrus reticulata), where $\mathrm{A}=$ shade leaf and $\mathrm{B}=$ sun leaf.

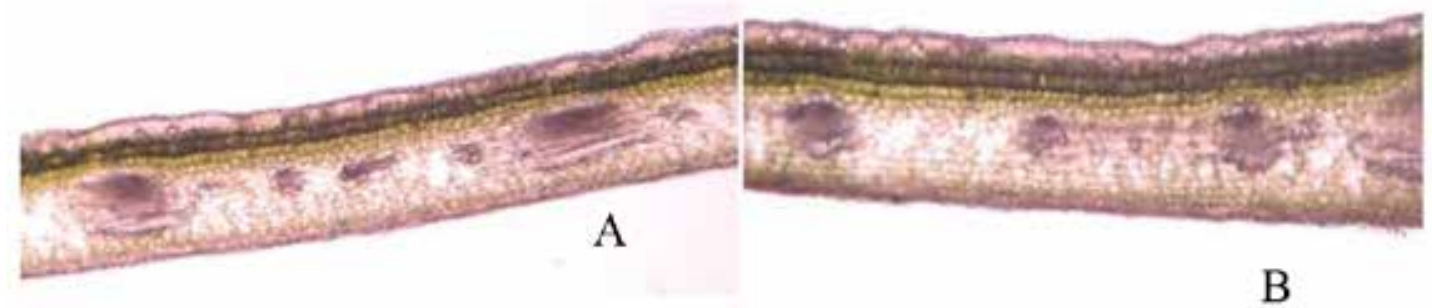

Figure 2. Cross sections of leaf blade of Ponkan tangerine (Citrus reticulata), where $\mathrm{A}=$ shade leaf and $\mathrm{B}=$ sun leaf.

is greater, with balance being established at a lower concentration. Boardman (1977) stresses that shade leaves have higher concentration of chlorophyll than sun leaves.

The chlorophyll $\mathrm{a} / \mathrm{b}$ ratio was greater for sun leaves, due to their higher content of chlorophyll a. According to Taiz \& Zeiger (2004) shade leaves have a greater amount of chlorophyll per reaction center, their chlorophyll a/b ratio is greater, and they are usually thinner than the sun leaves. The different ecophysiological responses observed between the plants of the same species in different sites are influenced by leaf structure and concentration of pigments in the leaves, as well as the existing microenvironmental variability (Pezzopane et al., 2002).

The findings of this study showed that the solar radiation regime does not differ between shade and sun leaves, which implies that plants in shade and those exposed to bright sunlight are acclimatized to the respective schemes of photosynthetically active solar radiation.

\section{Literature Cited}

Atroch, E.M.A.C.; Soares, A.M.; Alvarenga, A.A.; Castro, E.M. 2001. Crescimento, teor de clorofilas, distribuição de biomassa e características anatômicas de plantas jovens de Bauhinia forticata LINK submetidas à diferentes condições de sombreamento. Ciência e Agrotecnologia, 25 (4): 853-862. Arnon, D.I.

1949. Copper enzymes in isolatad chloroplasts. Palyphinoloxidare in Beta vulgaris. Plant Physiology, 24 (1): 1-15.
Boardman, N.K.

1977. Comparative photosynthesis of sun and shade plants. Annual Review of Plant Physiology, 28: 355-377.

Brakke, M.; Allen, Jr., L. H.

1995. Gas exchange of Citrus seedlings at different temperatures, vapor-pressure deficits, and soil water content. Journal of the American Society for Horticultural Science, 120: 497-504. 
Chaves, M.M.

1991. Effects of water deficits on carbon assimilation. Journal of Experimental Botany, Oxford, 42: 1-16.

Figueiredo, J.O.

1999. Cultivares de laranjas no Brasil. Simpósio Internacional de Fruticultura, Botucatu, 1: 87-108.

Figueiredo, J.O.

1991. Variedades copa de sabor comercial. In: Citricultura brasileira. Rodriguez, O.; Viegas, F.; Pompeu Junior, J.; Amaro, A.A. (Ed.).Campinas: Fundação Cargil, pp. 228-264.

Gratani, L.; Covone, F.; Larcher, W.

2006. Leaf plasticity in response to light of three evergreen species of the Mediterranean maquis. Trees, 20: 549-558.

Kaiser, W.M.

1987. Effects of water deficit on photosynthetic capacity. Physiologia Plantarum, 71: 142-149.

Kramer, P. J.; Kozlowski, T.

1979. Physiology of Woody Plants. New York, 811 p.

Lawlor, D.W.; Boyle, F.A.; Kendall, A.C; Keys, A.J.

1987. Nitrate nutrition and temperature effects on wheat: Enzyme composition, nitrate and total amino acid content of leaves. Journal of Experimental Botany, 38: 378-392.

Medina, C.L.; Machado, E.C.; Gomes, M.M.A.

1999. Condutância estomática, transpiração e fotossíntese em laranjeira 'Valência' sob deficiência hídrica. Revista Brasileira de Fisiologia Vegetal, 11: 29-34.
Mitchell, R.L.

1979. Crop Growth and Culture. Ames, The Iowa State University Press, 349 p.

Nakazono, E.M.; Costa, M.C.; Futatsugi, K.; Paulilo, M.T.S. 2001. Crescimento inicial de Euterpe edulis Mart em diferentes regimes de luz. Revista Brasileira de Botânica, 24 (2): 173-179.

Piel, C.; Frak, E.; Roux, X.L.; Genty, B.

2002. Effect of local irradiance on $\mathrm{CO}_{2}$ transfer in wainut. Journal of Experimental Botany, 53 (379): 2423-2430.

Pezzopane, J.E.M.; Reis, G.G.; Reis, M.G.F. Higuchi, P.; Polli, H.Q. 2002. Aspectos ecofisiológicos de algumas espécies arbóreas em uma floresta estacional semidecidual secundária. Revista Brasileira de Agrometeorologia, 10 (2): 273-281.

Syvertsen, J.; Lhoyd, J. J.

1994. Citrus In: Schaffer, B.; Anderson, P.C. Handbook of environmental physiology of fruits crops. Sub-tropical and tropical crops. Florida, pp. 65-99.

Taiz. L.; Zeiger, E.

2004. Fisiologia Vegetal. 3 ed., Porto Alegre, 719 p.

Thornber, J. P.

1975 Chlorophyll-proteins: light-harvesting and reaction center components of plants. Annual Review of Plant Physiology, 26: $127-158$.

Whatley, J.M.; Whatley, F.R.

1982. A luz e a vida das plantas. São Paulo, EPU-EDUSP, $101 \mathrm{p}$. 
